\title{
Kinetics and Autoradiography of High Affinity Uptake of Serotonin by Primary Astrocyte Cultures ${ }^{1}$
}

\author{
D. M. KATZ AND H. K. KIMELBERG*,2 \\ Division of Neurosurgery and * Departments of Biochemistry and Anatomy, Albany Medical College, Albany, New York 12208
}

\begin{abstract}
Primary astrocyte cultures prepared from the cerebral cortices of neonatal rats showed significant accumulation of serotonin (5-hydroxytryptamine; $\left[{ }^{3} \mathrm{H}\right]-5-\mathrm{HT}$ ). At concentrations in the range of 0.01 to $0.7 \mu \mathrm{M}\left[{ }^{3} \mathrm{H}\right]-5-\mathrm{HT}$, this uptake was 50 to $85 \% \mathrm{Na}^{+}$dependent and gave a $K_{\mathrm{m}}$ of $0.40 \pm 0.11 \mu \mathrm{M}\left[{ }^{3} \mathrm{H}\right]$ $-5-\mathrm{HT}$ and a $V_{\max }$ of $6.42 \pm 0.85$ ( $\left.\pm \mathrm{SEM}\right)$ pmol of $\left[{ }^{3} \mathrm{H}\right]-5-\mathrm{HT} /$ mg of protein/4 min for the $\mathrm{Na}^{+}$-dependent component. In the absence of $\mathrm{Na}^{+}$the uptake was nonsaturable. Omission of the monoamine oxidase inhibitor pargyline markedly reduced the $\mathrm{Na}^{+}$-dependent component of $\left[{ }^{3} \mathrm{H}\right]-5-\mathrm{HT}$ uptake but had a negligible effect on the $\mathrm{Na}^{+}$-independent component. This suggests significant oxidative deamination of serotonin after it has been taken up by the high affinity system, followed by release of its metabolite. We estimated that this system enabled the cells to concentrate $\left[{ }^{3} \mathrm{H}\right]-5-\mathrm{HT}$ up to 44-fold at an external $\left[{ }^{3} \mathrm{H}\right]-5-\mathrm{HT}$ concentration of $10^{-7}$ M. Inhibition of $\left[{ }^{3} \mathrm{H}\right]-5-\mathrm{HT}$ uptake by a number of clinically effective antidepressants was also consistent with a specific high affinity uptake mechanism for 5-HT, the order of effectiveness of inhibition being chlorimipramine > fluoxetine > imipramine $=$ amitriptyline $>$ desmethylimipramine $>$ iprindole $>$ mianserin. Uptake of $\left[{ }^{3} \mathrm{H}\right]-5-\mathrm{HT}$ was dependent on the presence of $\mathrm{Cl}^{-}$as well as $\mathrm{Na}^{+}$in the medium, and the effect of omission of both ions was nonadditive. Varying the concentration of $\mathrm{K}^{+}$in the media from 1 to $50 \mathrm{~mm}$ had a limited effect on [ $\left.{ }^{3} \mathrm{H}\right]-5-\mathrm{HT}$ uptake. Autoradiography of cultures after uptake of $\left[{ }^{3} \mathrm{H}\right]-5-\mathrm{HT}$ with $\mathrm{Na}^{+}$present showed that virtually all of the cells had a grain density that was above background and that this uptake was greatly reduced when $\mathrm{Na}^{+}$was omitted from the medium. These data show that, based on kinetic parameters, ionic dependence, and the pharmacology of inhibition, uptake of $\left[{ }^{3} \mathrm{H}\right]-5-\mathrm{HT}$ by primary astrocyte cultures at submicromolar concentrations of $5-\mathrm{HT}$ is indistinguishable from the high affinity uptake reported for brain tissue. High affinity uptake of serotonin has been thought to be an exclusively neuronal property, but the present findings support the concept that astroglia can also show this property.
\end{abstract}

Received October 11, 1984; Revised December 4, 1984;

Accepted December 4, 1984

1 This work was supported by National Institute of Neurological Communicative Disorders and Stroke Grant NS 19492 to H. K. K. We wish to thank Dr. Peter del Vecchio for use of his Nikon Labophot microscope, Dr. D. Treble for use of his computer program in relation to the data shown in Figure 3, and Drs. G. A. Banker, C. L. Bowman, J. E. Mazurkiewicz, and R. Waniewski for helpful discussions on several aspects of this work

${ }^{2}$ To whom correspondence should be addressed.
Termination of the extracellular action of a number of neurotransmitters in the CNS is thought to be due to compartmental sequestration by specific reuptake into the nerve endings from which they were released. It is now becoming clear, however, that uptake of neurotransmitters after release need not only be by reuptake into the nerve endings, but can also involve uptake into glial cells. Uptake of amino acid transmitters by glial cells has been observed in a number of different experimental systems (Fonnum et al., 1980). Uptake of monoamine transmitters, including serotonin (5-hydroxytryptamine; $5-\mathrm{HT}$ ), by several glial preparations has also been reported (Henn and Hamberger, 1971; Pfister and Goworek, 1977; Suddith et al., 1978; Hoffman and Vernadakis, 1979; Pelton et al., 1981; Ritchie et al., 1981; Tardy et al., 1982; Kimelberg and Pelton, 1983; Whitaker et al., 1983). The properties of serotonin uptake into glial cells, however, generally showed some differences from high affinity uptake into brain (see "Discussion"). In this study we have examined both the kinetics of $\left[{ }^{3} \mathrm{H}\right]-5-\mathrm{HT}$ uptake and its inhibition by clinically effective antidepressants in a well characterized rat primary astrocyte culture which is predominantly astrocytic ( $\geq 95 \%$ astrocytes) (Kimelberg, 1983). We show that these cultures have a high affinity uptake system for serotonin which shows the same kinctics of uptake and pharmacology of inhibition as does the high affinity uptake system reported for mammalian brain. Using autoradiography, we also show localization of uptake to almost all of the cells in these cultures. A preliminary report of this work has been presented (Kimelberg and Katz, 1984).

\section{Materials and Methods}

Primary astrocyte cultures from neonatal rat cerebral cortices were grown in 12-well trays (Costar) as described recently (Frangakis and Kimelberg, 1984). To measure uptake of $\left[{ }^{3} \mathrm{H}\right]-5-\mathrm{HT}$, growth medium was removed and each well was washed three times with $1 \mathrm{ml}$ of a $\mathrm{HCO}_{3}{ }^{-}$-buffered medium (in millimoles per liter: $\mathrm{Na}^{+}, 145 ; \mathrm{K}^{+}, 4.5 ; \mathrm{Mg}^{2+}, 0.4 ; \mathrm{Ca}^{2+}, 1.3 ; \mathrm{Cl}^{-}, 127$; $\mathrm{SO}_{4}{ }^{2-}, 0.4 ; \mathrm{HCO}_{3}{ }^{-}, 25$; glucose, $10 ; \mathrm{pH} 7.4$ ) at $37^{\circ} \mathrm{C}$. When $\mathrm{Na}^{+}$was omitted it was replaced with choline. The cells were then allowed to incubate with 1 $\mathrm{ml}$ of the medium/well at $37^{\circ} \mathrm{C}$ in a $95 \%$ air $/ 5 \% \mathrm{CO}_{2}$ atmosphere for $20 \mathrm{~min}$ in a Wedco incubator. Inhibitors, when added, were present during this preincubation period. After the preincubation period, identical warmed medium, but now containing $\left[{ }^{3} \mathrm{H}\right] 5 \mathrm{HT}$, was added. After completion of the uptake period (usually $4 \mathrm{~min}$ but sometimes longer), the cells were rapidly washed seven times by rapid addition and immediate aspiration of $1 \mathrm{ml}$ of ice-cold $0.32 \mathrm{M}$ sucrose, buffered with $10 \mathrm{~mm}$ Tris- $\mathrm{HCl}, \mathrm{pH}$ 7.4. A zero tirne uptake, measured by adding $\left[{ }^{3} \mathrm{H}\right]-5-\mathrm{HT}$ and immediately washing the cells, was always subtracted to correct for the small equivalent volume $(\sim 0.2$ microlter) of adherent media left after washing. In all cases, unless specified otherwise, $10^{-4} \mathrm{M}$ pargyline was added to prevent oxidative deamination of $5-\mathrm{HT}$, and $10^{-5} \mathrm{M}$ ascorbate was present to prevent auto-oxidation of 5-HT The cells were then solubilized in $0.5 \mathrm{ml}$ of $1 \mathrm{~N} \mathrm{NaOH} /$ well at $37^{\circ} \mathrm{C}$ for 30 min. This was then diluted to $0.5 \mathrm{~N} \mathrm{NaOH}$ and aliquots were taken for scintillation counting and protein determinations (Kimelberg and Pelton, 1983).

Autoradiography. For autoradiography, primary astrocyte cultures were grown on glass coverslips in 60-mm dishes (Corning). Cells were allowed to incubate with $0.3 \mu \mathrm{M}\left[{ }^{3} \mathrm{H}\right]-5-\mathrm{HT}$ in $\mathrm{HCO}_{3}{ }^{-}$-buffered medium for $30 \mathrm{~min}$ in the 


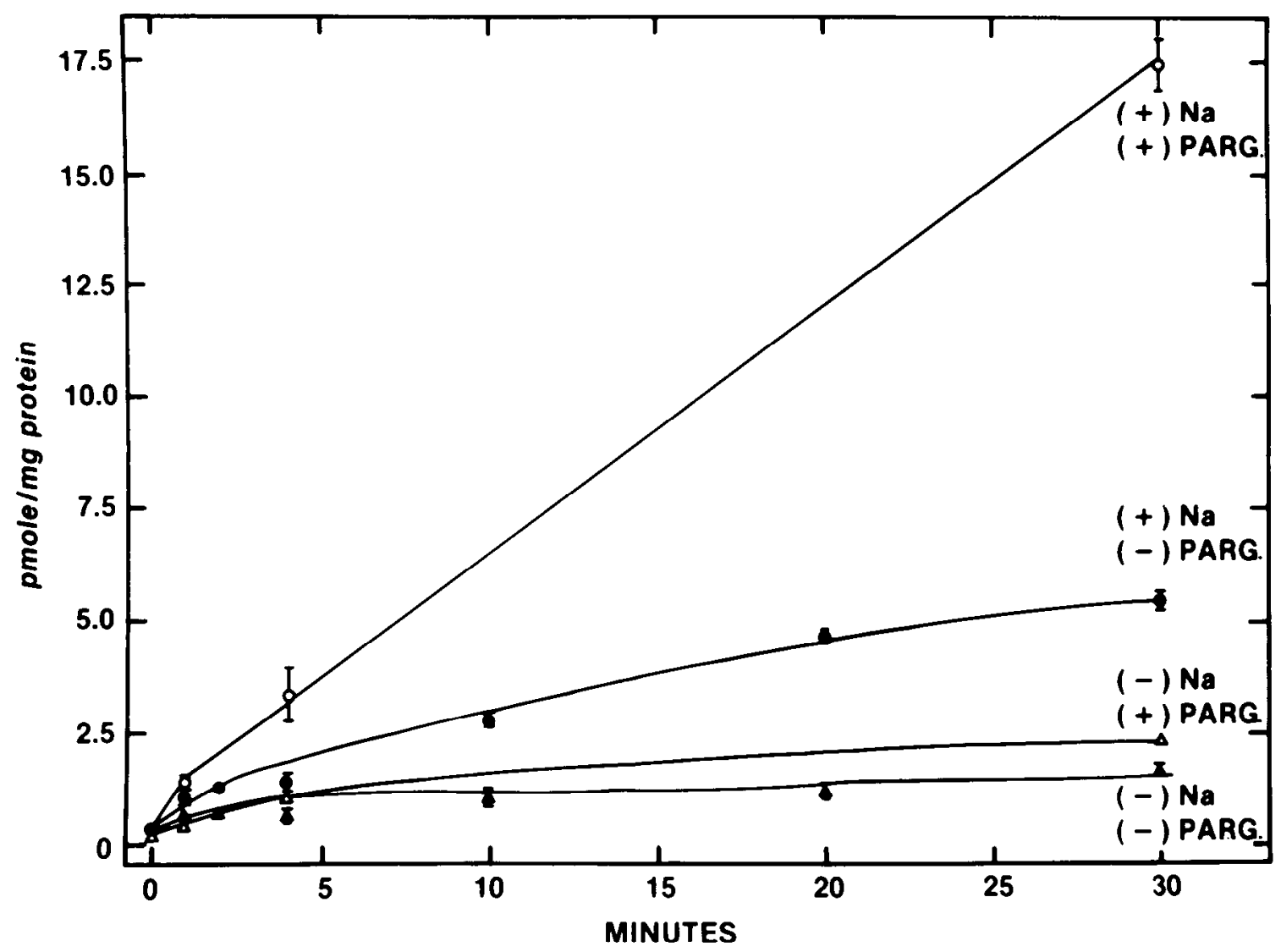

Figure 1. Effect of omission of medium $\mathrm{Na}^{+}$and pargyline (PARG.) on $\left[{ }^{3} \mathrm{H}\right]-5-\mathrm{HT}$ uptake. Uptake of $\left[{ }^{3} \mathrm{H}\right]-5-\mathrm{HT}$ at a final concentration of $10^{-7} \mathrm{M}$ was measured at $37^{\circ} \mathrm{C}$ as described under "Materials and Methods" at varying times in the presence $(+)$ and absence $(-)$ of $\mathrm{Na}^{+}$and $10^{-4} \mathrm{M} \mathrm{pargyline} \mathrm{as}$ indicated. When $\mathrm{Na}^{+}$in the medium was omitted, it was replaced with choline. Final medium $\left[\mathrm{K}^{+}\right]$was $4.5 \mathrm{~mm}$. Cells were 28 days old. Values are means \pm $\mathrm{SEM} ; n$ (number of wells per data point) $=3$.

presence of pargyline and ascorbate (see above). To stop uptake the cells were rapidly washed seven times with $2 \mathrm{ml}$ of ice-cold phosphate-buffered saline (PBS; $140 \mathrm{~mm} \mathrm{NaCl}, 3.5 \mathrm{~mm} \mathrm{NaH}_{2} \mathrm{PO}_{4}, 12 \mathrm{mM} \mathrm{Na}_{2} \mathrm{HPO}_{4}$, pH 7.25). The cells were then fixed in $4 \%$ glutaraldehyde in PBS for $20 \mathrm{~min}$ at room temperature. After washing with PBS to remove the fixative, the coverslips were air dried, mounted on microscope slides with Fluormount, and left overnight at $4^{\circ} \mathrm{C}$ to dry. The slides were then dipped in the dark in Kodak NTB2 nuclear track emulsion at $41^{\circ} \mathrm{C}$, air dried for $1 \mathrm{hr}$, and allowed to develop at $4^{\circ} \mathrm{C}$ for 9 days. The slides were then developed in Kodak Dektol (1:2) for $2 \mathrm{~min}$, stopped in 1\% acetic acid for $30 \mathrm{sec}$, fixed in Kodak fixer for $4 \mathrm{~min}$, and finally rinsed in three water baths for $5 \mathrm{~min}$ each. They were viewed using a Nikon Labophot.

Materials. 5-Hydroxy-[G- $\left.{ }^{3} \mathrm{H}\right]$ tryptamine creatinine sulfate was from Amersham (specific activity, 9 to $23 \mathrm{Ci} / \mathrm{mmol}$ ). Pargyline hydrochloride was from Sigma Chemical Co. The different antagonists used were generous gifts of different pharmaceutical companies, as follows: fluoxetine, Eli Lilly and Co.; chlorimipramine and imipramine hydrochloride, CIBA Pharmaceuticals; desmethylimipramine, USV Pharmaceuticals; amitriptyline hydrochloride, Merck, Sharp and Dohme; mianserin hydrochloride, Organon International B.V.: iprindole hydrochloride, Wyeth Laboratories.

\section{Results}

A time course for the uptake of $\left[{ }^{3} \mathrm{H}\right]-5-\mathrm{HT}$ at $10^{-7} \mathrm{M}$ and the effects of $\mathrm{Na}^{+}$and pargyline are shown in Figure 1. In the presence of $10^{-4}$ $M$ pargyline the uptake is clearly greater than in its absence and at $30 \mathrm{~min}$ an intracellular concentration of $4.4 \times 10^{-6} \mathrm{M}$ can be calculated based on an intracellular volume of about $4 \mu \mathrm{l}$ (Kimelberg et al, 1979; Kimelberg and Pelton, 1983) and an uptake of $17.5 \mathrm{pmol}$ of $\left[{ }^{3} \mathrm{H}\right]-5-\mathrm{HT} / \mathrm{mg}$ of protein. It can be seen that the uptake is still increasing with time and has not yet reached a steady state by 30 min. The uptake of $\left.{ }^{3} \mathrm{H}\right]-5-\mathrm{HT}$ was also markedly dependent on the presence of $\mathrm{Na}^{+}$in the medium. However, the magnitude of the $\mathrm{Na}^{+}$ dependence was reduced when pargyline was absent. For $\mathrm{Na}^{+}$. independent uptake there was essentially no effect due to omission of pargyline.

The marked dependence of $\left[{ }^{3} \mathrm{H}\right]-5-\mathrm{HT}$ uptake on medium $\mathrm{Na}^{+}$ clearly indicates that this component of uptake is of the high affinity type (Snyder, 1970; Iversen, 1974; Fonnum et al. (1980). This was further supported by kinetic studies, the results of which are shown in Figure 2. Initial rates of uptake of $\left[{ }^{3} \mathrm{H}\right]-5-\mathrm{HT}$ over 4 min were measured as a function of varying $\left[{ }^{3} \mathrm{H}\right]-5-\mathrm{HT}$ concentrations in the presence and absence of $\mathrm{Na}^{+}$in the medium. The $\mathrm{Na}^{+}$-sensitive component (see Fig. 2 legend) was clearly saturable, whereas the $\mathrm{Na}^{+}$-insensitive component increased linearly with increasing $\left[{ }^{3} \mathrm{H}\right]-5$ HT concentration and showed no saturation within the concentration range studied, as determined by fitting the data to a computer program (see Fig. 2 legend). The $K_{m}$ for the $\mathrm{Na}^{+}$-sensitive component was $0.40 \pm 0.11 \mu \mathrm{M}$ and the $V_{\max }$ was $6.42 \pm 0.85 \mathrm{pmol} / \mathrm{mg}$ of protein $/ 4 \mathrm{~min}( \pm \mathrm{SEM}$ ) as obtained from the computer program.

High affinity uptake of monoamines is also dependent on $\mathrm{Cl}^{-}$ (Fonnum et al., 1980). In Figure 3 we show that omission of $\mathrm{Cl}^{-}$ from the medium reduced $\left[{ }^{3} \mathrm{H}\right]-5-\mathrm{HT}$ uptake by the same amount as when $\mathrm{Na}^{+}$was omitted. Also, the omission of both ions did not show any additivity. We also looked for any dependence of $\left[{ }^{3} \mathrm{H}\right]-5-\mathrm{HT}$ uptake on varying external $\left[\mathrm{K}^{+}\right]_{\mathrm{o}}$. The effect of varying $\left[\mathrm{K}^{+}\right]_{\mathrm{o}}$ from 1 to $50 \mathrm{~mm}$ is shown in Figure 4, where it is compared with the dependence of $\left[{ }^{3} \mathrm{H}\right]-5-\mathrm{HT}$ uptake on varying $\left[\mathrm{Na}^{+}\right]_{0}$. There was a sharp, $37 \%$ increase in $\left[{ }^{3} \mathrm{H}\right]-5-\mathrm{HT}$ uptake from 1 to $6 \mathrm{mM} \mathrm{K}^{+}$, but this was followed by a decline, with an essentially constant rate of $\left[{ }^{3} \mathrm{H}\right]$ $5-\mathrm{HT}$ uptake being found from 10 to $50 \mathrm{~mm} \mathrm{~K}^{+}$. In contrast, there was a marked increase in the rate of uptake of $\left[{ }^{3} \mathrm{H}\right]-5-\mathrm{HT}$ from about 25 to $45 \mathrm{mM} \mathrm{Na}^{+}$to a relativity constant level, with maximum levels being reached at 100 to $150 \mathrm{mM} \mathrm{Na}$.

High affinity uptake of $\left[{ }^{3} \mathrm{H}\right]-5-\mathrm{HT}$ in the CNS is specifically sensitive 


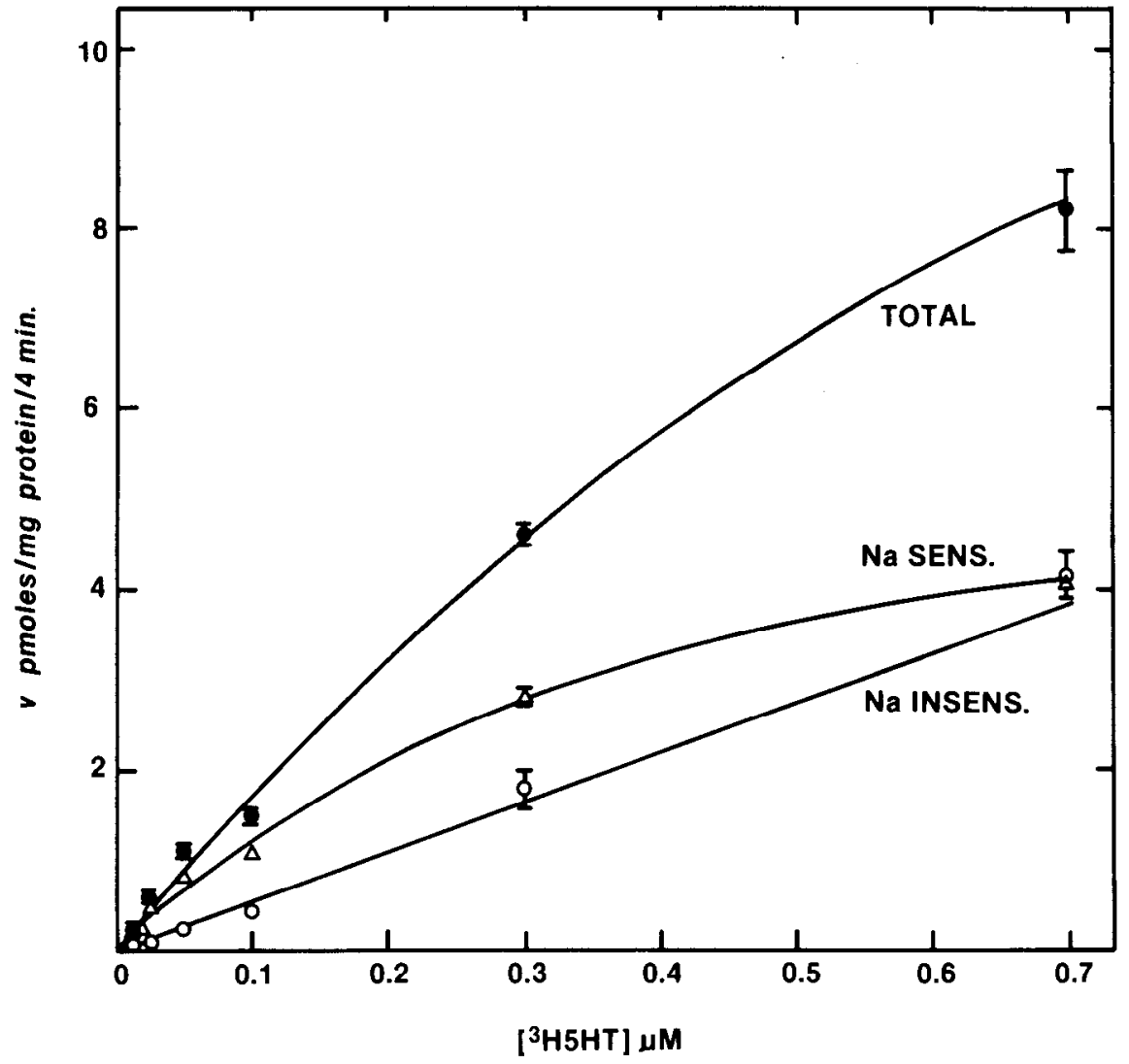

Figure 2. Dependence of $\left[{ }^{3} \mathrm{H}\right]-5-\mathrm{HT}$ uptake on the concentration of $\left[{ }^{3} \mathrm{H}\right]-5-\mathrm{HT}$. Varying amounts of $\left[{ }^{3} \mathrm{H}\right]-$ 5-HT were added to give the final concentrations shown, and uptake was measured in the presence and absence of medium $\mathrm{Na}^{+}$. $\mathrm{Na}^{+}$was replaced with choline. Uptake of $\left[{ }^{3} \mathrm{H}\right]-5-\mathrm{HT}$ was measured for $4 \mathrm{~min}$. Cells were 25 days old. Each point is the mean \pm SEM of values from three separate wells. The $\mathrm{Na}^{+}$dependent curve was obtained by subtracting the uptake in the absence of $\mathrm{Na}^{+}$from total uptake. The curves were generated using a computer program for fitting data to the Michaelis-Menton equation based on the method of Bliss and James (1966) as previously described (Kimelberg and Pelton, 1983). The $\mathrm{Na}^{+}$-dependent component was best fitted by a curve which gave a $K_{\mathrm{m}}$ of $0.40 \pm 0.11 \mu \mathrm{M}$ and a $V_{\max }$ of $6.42 \pm 0.85 \mathrm{pmol} / \mathrm{mg}$ of protein $/ 4 \mathrm{~min}$.

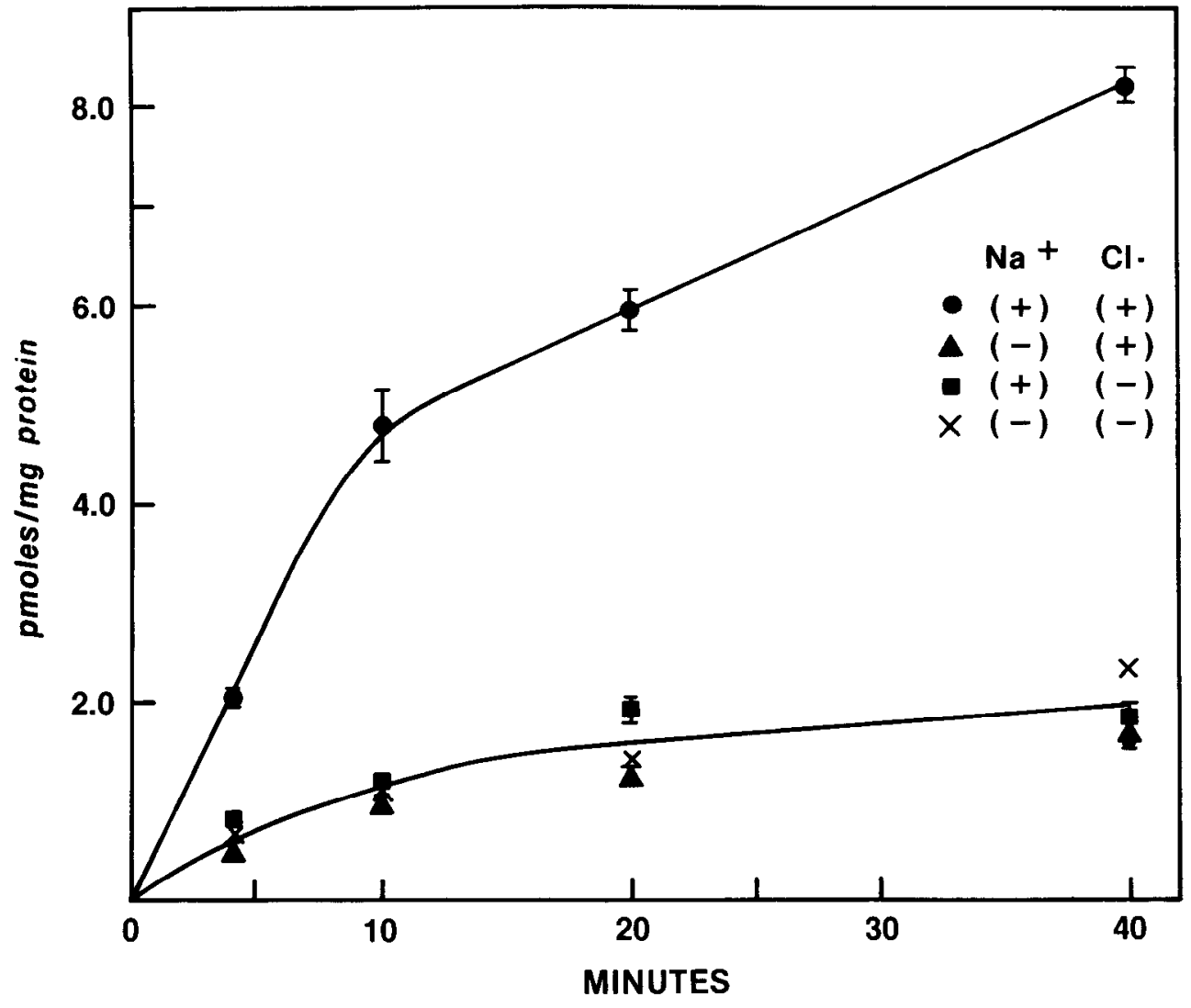

Figure 3. Effects of omission of $\mathrm{Na}^{+}$or $\mathrm{Cl}^{-}$or both on $\left[{ }^{3} \mathrm{H}\right]-5-\mathrm{HI}\left(10^{-7} \mathrm{M}\right)$ uptake measured for $4 \mathrm{~min}$. $\mathrm{Na}^{+}$was replaced with choline and $\mathrm{Cl}^{-}$was replaced with isethionate. The presence of $\mathrm{Na}^{+}$and $\mathrm{Cl}^{-}$ is indicated in the code on the figure as $(+)$, and omission is indicated as $(-)$ for the different symbols. Cells were 35 days old. Each point represents the mean \pm $\mathrm{SEM} ; n=4$. 


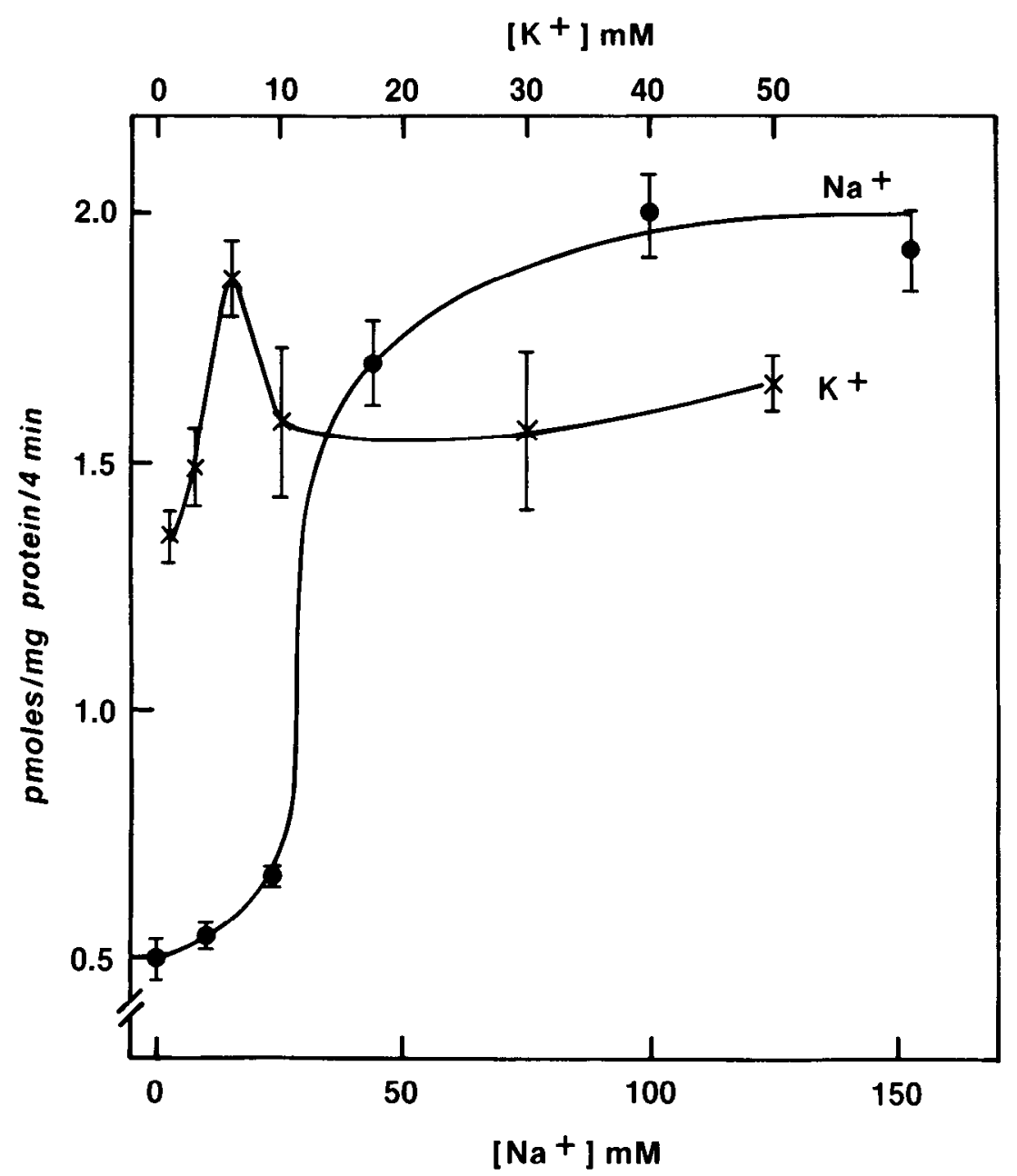

Figure 4. Effects of varying the medium concentrations of $\mathrm{Na}^{+}$or $\mathrm{K}^{+}$on $\left[{ }^{3} \mathrm{H}\right]-5-\mathrm{HT}$ uptake. Uptake of $\left[{ }^{3} \mathrm{H}\right]-5-\mathrm{HT}$ was measured over a 4-min period. When $\left[\mathrm{Na}^{+}\right]_{0}$ was varied, it was replaced with choline. When $\mathrm{K}^{+}$was varied, $\left[\mathrm{Na}^{+}\right]_{0}$ was reciprocally altered to maintain constant osmolarity. Cells were 34 days old. Values are mean $\pm \operatorname{SEM} ; n=4$. to a number of antagonists, including a variety of clinically effective antidepressants (Iversen, 1974; Fonnum et al., 1980; Green and Costain, 1981). The effects of varying concentrations of a number of these antagonists on the uptake of $\left[{ }^{3} \mathrm{H}\right]-5-\mathrm{HT}$ are shown in Figure 5 . The range of the percentage of $\mathrm{Na}^{+}$independent uptake found for the different cultures is also indicated and, as can be seen, all of the inhibitors seemed to inhibit approximately to this level. $I C_{50}$ values for $50 \%$ inhibition of the $\mathrm{Na}^{+}$-sensitive component alone were obtained from all of these dose-response curves by inspection and are surmmarized in Table $I$ in the lirsl column. In the second column $K_{d}$ values are shown, which were obtained by fitting the data to a ligand-binding curve program assuming competitive inhibition and using the $K_{m}$ value of $0.40 \mu \mathrm{M}$ found in this study for $\left[{ }^{3} \mathrm{H}\right]-5-\mathrm{HT}$ and subtracting the $\mathrm{Na}^{+}$-independent component.

Figure 6 shows autoradiography of cells grown on coverslips incubated with $0.3 \mu \mathrm{M}\left[{ }^{3} \mathrm{H}\right]-5 . \mathrm{HT}$ for $30 \mathrm{~min}$ and fixed with $4 \%$ glutaraldehyde as described under "Materials and Methods." Figure $6 A$ is a brightfield photomicrograph showing uptake in an area of a culture containing predominantly flat cells. Figure $6 B$ is the corresponding phase contrast photomicrograph of the same field. As can be seen, all of the cells show a high grain density which was well above the background density seen in the cell-free areas between cells. One cell with an extremely high grain density is also present in the middle of the field. Examination of regions from all areas of the coverslip did not reveal any cells which did not show grain density above background. Figure $6 \mathrm{C}$ represents an area with an intermediate grain density, and Figure $6 D$ shows the corresponding phase contrast micrograph. In this figure, both process-bearing cells and flat cells were present, both showing a grain density clearly greater than background. Figure $6 E$ shows an area which represents the least intense uptake seen; Figure $6 F$ is the corresponding phase contrast micrograph showing that the area contains a confluent monolayer of cells with the characteristic flat morphology of primary astrocyte cultures (Kimelberg, 1983). When $\mathrm{Na}^{+}$was omitted from the medium during the initial incubation with [ $\left.{ }^{3} \mathrm{H}\right]-5-\mathrm{HT}$, all of the cells showed a grain density almost identical to background levels as shown in figure $6 \mathrm{G}$. Figure $6 \mathrm{H}$ is the corresponding phase micrograph showing the areas of the field which contained cells and the area which was cell free. This field was chosen so that a direct comparison can be made of the grain density in the two areas. Results essentially similar to those shown in Figure 6 were obtained for one other culture. Since our cultures stain $95 \%$ or better for glial fibrillary acidic protein (GFAP) (Kimelberg, 1983; H. K. Kimelberg and $M$. V. Frangakis, unpublished data), which included all of the morphological types in the autoradiographs which took up ${ }^{3} \mathrm{H}$ label, these results strongly suggest that $\mathrm{GFAP}(+)$ cells are taking up $\left[{ }^{3} \mathrm{H}\right]-5-\mathrm{HT}$.

\section{Discussion}

The characteristics of the uptake of $\left[{ }^{3} \mathrm{H}\right]-5-\mathrm{HT}$ by primary astrocyte cultures found in this study closely resembles that described for high affinity uptake of $\left[{ }^{3} \mathrm{H}\right]-5-\mathrm{HT}$ by brain slices and subcellular fractions. These similarities include an apparent $K_{\mathrm{m}}$ of 0.11 to 0.30 $\mu \mathrm{M}$, reasonably close to our value of $0.40 \mu \mathrm{M}$, and uptake which is $\mathrm{Na}^{+}$dependent (Shaskan and Snyder, 1970; Iversen, 1974; Fonnum ct al., 1980). Quantitativcly, our uptake is within an order of magnitude of that described for in vitro brain preparations. If we assume that $1 \mathrm{gm}$ of brain represents $100 \mathrm{mg}$ of protein (Hertz, 1982), then Shaskan and Snyder (1970) found $V_{\max }$ values in rat brain striatal or hypothalamic slices which convert to $\uparrow 1.2$ to 14.0 pmol of $\left[{ }^{3} \mathrm{H}\right]-5$ $\mathrm{HT} / \mathrm{min} / \mathrm{mg}$ of protein taken up. Our value is $1.6 \mathrm{pmol}$ of $\left[{ }^{3} \mathrm{H}\right]-5-\mathrm{HT} /$ $\mathrm{mg}$ of protein/min. This lower value may reflect an actual lower 


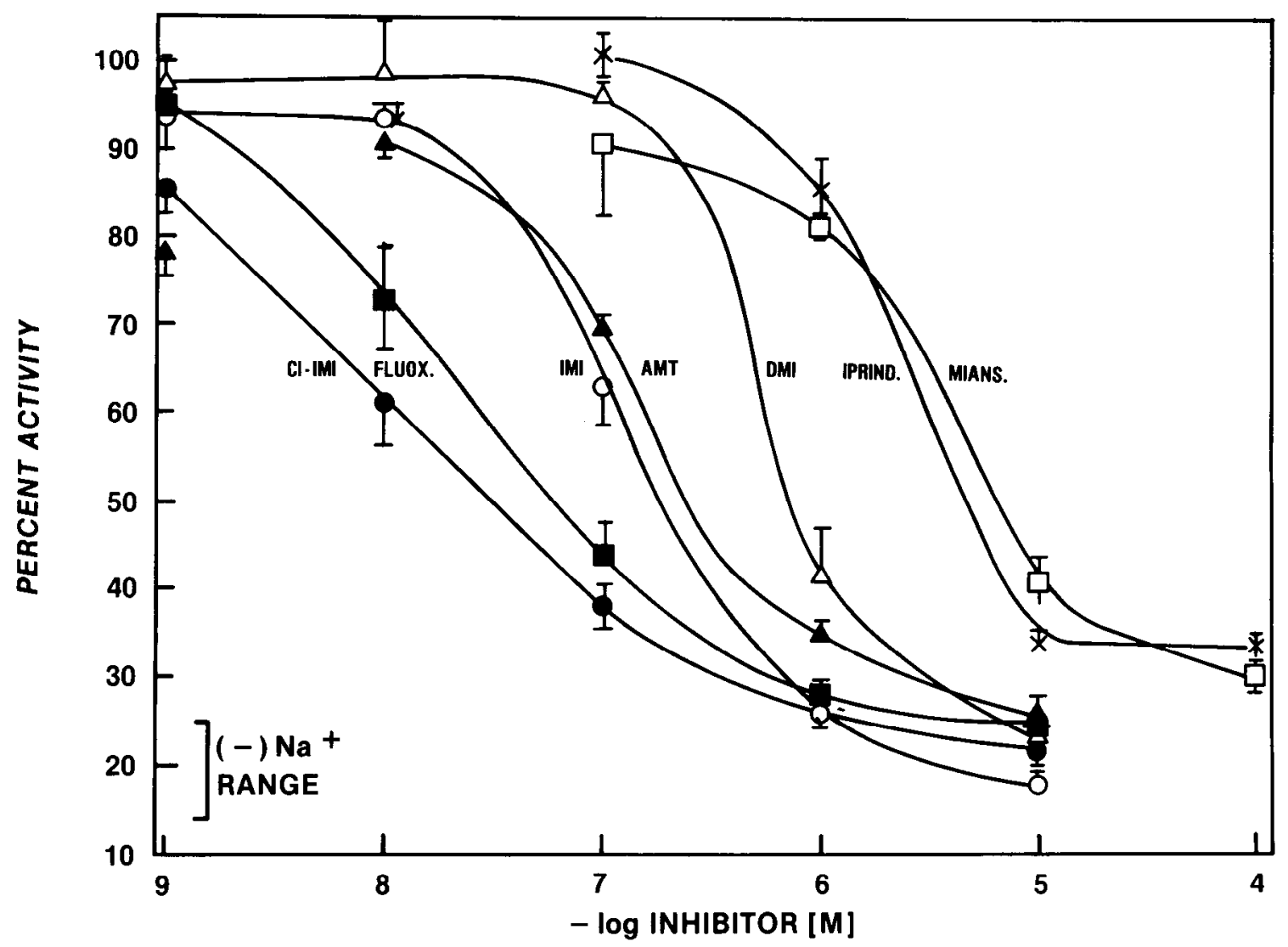

Figure 5. Effects of different clinically effective antidepressants on $\left[{ }^{3} \mathrm{H}\right]-5-\mathrm{HT}$ uptake. All of the antagonists shown were present during the 20 -min preincubation period (see Materials and Methods). Uptake of $10^{-7} \mathrm{M}\left[{ }^{3} \mathrm{H}\right]-5-\mathrm{HT}$ was measured for $4 \mathrm{~min}$. The age of the cells from different cultures ranged from 22 to 33 days old. Percent activity refers to the control value in the presence of $\mathrm{Na}^{+}$for each different culture used. The (-) $\mathrm{Na}^{+}$range refers to the range of uptake found in the absence of medium $\mathrm{Na}^{+}$for each culture as a percentage of the control value in the presence of $\mathrm{Na}^{+}$. Values are means \pm SEM; $n=4$. Cl-IMI, chlorimipramine; FLUOX., fluoxetine; IMI, imipramine; AMT, amitriptyline; DMI, desmethylimipramine; IPRIND., iprindole; MIANS., mianserin.

TABLE ।

$I C_{50}$ values for inhibition of $\mathrm{Na}^{+}$-sensitive $\left.{ }^{3} \mathrm{H}\right]-5-\mathrm{HT}$ uptake

Data were obtained by inspection (shown as $\mathrm{IC}_{50}$ ) of curves in Figure 5 or by fitting the data points shown in Figure 5 to a ligand-binding curve written by P. Munson, A. de Lean, and D. Rodland and modified for an Apple ॥ microcomputer by $\mathrm{M}$. $\mathrm{H}$. Teicher (shown as $K_{\mathbf{d}}$ values). A $K_{m}$ value for $\mathrm{5}-\mathrm{HT}$ of $0.40 \mu \mathrm{M}$ was used throughout, competitive inhibition was assumed, and the $\mathrm{Na}^{+}$-independent activity was subtracted.

\begin{tabular}{lcc}
\hline Compound & $\mathcal{C}_{50}(\mu \mathrm{M})$ & $K_{\mathrm{d}}(\mu \mathrm{M})$ \\
\hline Cl-IMI & 0.009 & $0.008 \pm 0.006^{a}$ \\
Fluoxetine & 0.023 & $0.038 \pm 0.026$ \\
IMl & 0.14 & $0.110 \pm 0.013$ \\
AMT & 0.14 & $0.108 \pm 0.055$ \\
DMI & 0.62 & $0.482 \pm 0.059$ \\
Iprindole & 2.8 & $1.21 \pm 0.82$ \\
Mianserin & 4.9 & $8.62 \pm 2.42$ \\
\hline
\end{tabular}

${ }^{a}$ Values are means $\pm \mathrm{SE}$.

transport capacity in astrocytes in situ compared to neurons, or that uptake is lower when the cells are grown in culture. Although the rates of uptake are lower, the concentrative capacity of the cells compared to brain slices seems unimpaired. Our estimated intracellular concentration of $4.4 \times 10^{-6} \mathrm{M}$ after a 30 -min incubation with $10^{-7} \mathrm{M}\left[{ }^{3} \mathrm{H}\right]-5-\mathrm{HT}$ (Fig. 1) gives a tissue-to-medium ratio value of 44 fold. This value exceeds the tissue-to-medium ratio of 21 at $10^{-7} \mathrm{M}$ $\left[{ }^{3} \mathrm{H}\right]-5-\mathrm{HT}$ estimated by Shaskan and Snyder (1970) for tissue slices from rat corpus striatum, the region in which the greatest $\left[{ }^{3} \mathrm{H}\right]-5-\mathrm{HT}$ uptake was found. Also, uptake of $\left[{ }^{3} \mathrm{H}\right]-5-\mathrm{HT}$ had not yet reached a steady state by $30 \mathrm{~min}$, so that even higher intracellular concentrations of $\left[{ }^{3} \mathrm{H}\right]-5-\mathrm{HT}$ would seem to be attainable. Generally, monoamine oxidase (MAO) inhibitors are added to inhibit metabolism of $5-\mathrm{HT}$, and our finding that pargyline is needed to achieve maximal uptake of $\left[{ }^{3} \mathrm{H}\right]-5-\mathrm{HT}$ is consistent with this. It is of interest that it is the $\mathrm{Na}^{\prime}$-dependent uptake that is mainly affected by the omission of pargyline. The effect of pargyline suggests that the metabolite of 5 -HT produced by MAO action (5-hydroxyindolacetic acid) is not retained as well as $5-\mathrm{HT}$ itself. Thus, the effect of omission of pargyline in decreasing $\left[{ }^{3} \mathrm{H}\right]-5-\mathrm{HT}$ uptake and steady-state content may be a consequence of a constant uptake but more rapid efflux.

$\mathrm{Na}^{+}$dependence has been shown for uptake of $5-\mathrm{HT}$ in brain slices and synaptosomes (Bogdanski et al., 1970; Shaskan and Snyder, 1970), and $\mathrm{Cl}^{-}$dependence for 5- $\mathrm{HT}$ uptake in platelets (Lindegjaerde, 1971). In contrast, increased $\left[\mathrm{K}^{+}\right]_{0}$ had a slight inhibitory effect (Bogdanski et al., 1970). The data in Figure 3 clearly show that the uptake by astrocytes is strongly $\mathrm{Na}^{+}$and $\mathrm{Cl}^{-}$dependent. Also, since the effects of simultaneous omission of $\mathrm{Na}^{+}$and $\mathrm{Cl}^{-}$ are not additive, it appears that the same uptake mechanism is affected by both these ions. The dependence of $\left[{ }^{3} \mathrm{H}\right]-5-\mathrm{HT}$ uptake on varying $\mathrm{Na}^{+}$concentrations shows a sharp increase between 25 and $45 \mathrm{~mm} \mathrm{Na}^{+}$with $50 \%$ stimulation at approximately 30 to $35 \mathrm{~mm}$ $\mathrm{Na}^{+}$. This is close to the value of $40 \mathrm{~mm}$ for an apparent $K_{\mathrm{m}}$ for $\mathrm{Na}^{+}$ stimulation of 5-HT uptake in synaptosomes reported by Bogdanski et al. (1970). There was much less $\mathrm{K}^{+}$dependence of $\left[{ }^{3} \mathrm{H}\right]-5-\mathrm{HT}$ uptake in astrocytes, although a small peak was found at $6 \mathrm{~mm}$ $\left[\mathrm{K}^{+}\right]_{0}$. When $\left[\mathrm{K}^{+}\right]_{0}$ was increased, $\left[\mathrm{Na}^{+}\right]_{\mathrm{o}}$ was concomitantly decreased. However, since a maximum effect was found at 100 to $150 \mathrm{mM} \mathrm{Na}^{+}$and $\mathrm{K}^{+}$was only increased to $50 \mathrm{mM}$, the lowest 

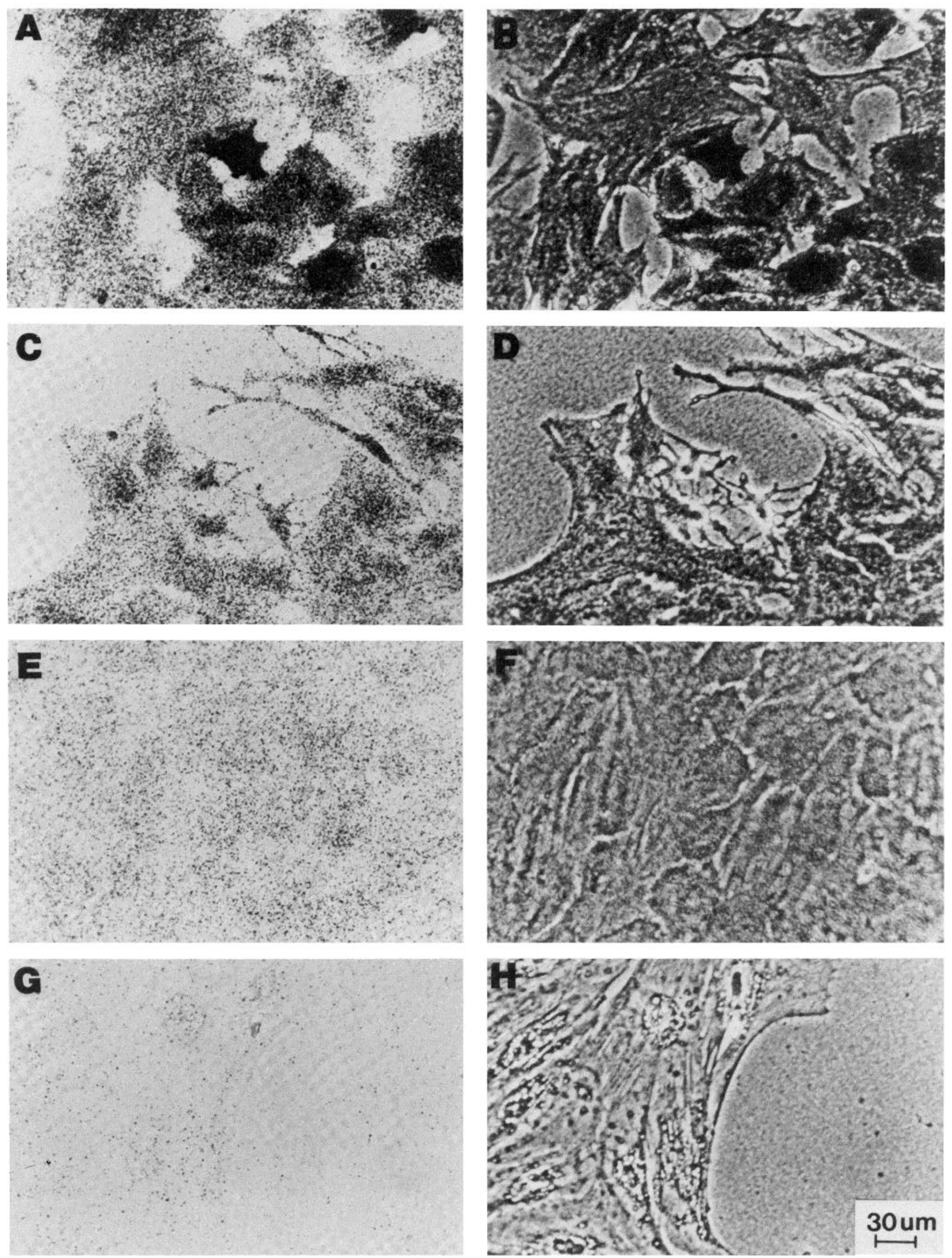

Figure 6. Autoradiography of cells after incubation with $\left[{ }^{3} \mathrm{H}\right]-5-\mathrm{HT}$. Uptake of $0.3 \mu \mathrm{M}\left[{ }^{3} \mathrm{H}\right]-5-\mathrm{HT}$ was allowed to proceed for 30 min in the presence of pargyline and ascorbate, and the cells were then fixed in $4 \%$ glutaraldehyde as described under "Materials and Methods." $A$ to $H$ are different fields of the same culture representative of the varying grain density found, as described in the text. $A$ to $F$ show cells in which uptake was measured in $\mathrm{Na}^{+}$-containing medium, and $\mathrm{G}$ and $\mathrm{H}$ are of cells in $\mathrm{Na}^{+}$-free medium. Cells were 5 weeks old and were left for 9 days before development of the emulsion. All photomicrographs on the left $(A, C, E, G)$ are brightfield and those on the right $(B, D, F, H)$ are phase contrast. 
$\left[\mathrm{Na}^{+}\right]_{0}$ used when $\mathrm{K}^{+}$was varied was $100 \mathrm{~mm}$ and therefore should not have been a factor. Such concentrations of $\left[\mathrm{K}^{+}\right]_{0}$ will, however, markedly depolarize the cells (Kimelberg et al., 1979). A $40 \%$ inhibition of 5-HT uptake was reported by Boydanski el al. (1970) in rabbit brainstem synaptosomes when $\mathrm{K}^{+}$was raised from 6 to 100 $\mathrm{mM} \mathrm{K}^{+}$at $50 \mathrm{mM} \mathrm{Na}^{+}$. However, this occurred with a higher $\left[\mathrm{K}^{+}\right]$ than we used and in the presence of reduced $\left[\mathrm{Na}^{+}\right]_{\mathrm{o}}$.

It has been shown in vitro that $5-\mathrm{HT}$ can also be taken up by catecholamine uptake systerris, and we have shown that such uptake systems are present in our primary astrocyte cultures (Pelton et al., 1981; Kimelberg and Pelton, 1983). We have not done any cross-inhibition studies, but the rank order of inhibition by a variety of antidepressants clearly conforms to the order shown for the 5-HT systern, which is different from that seen for the catecholamine system. Thus, Shaskan and Snyder (1970) found that the order of effectiveness for inhibition of $\left[{ }^{3} \mathrm{H}\right]-5-\mathrm{HT}$ uptake in hypothalamic slices was chlorimipramine $>$ imipramine $>$ desmethylimipramine with $\mathrm{IC}_{50}$ values of 3.0 to $4.5 \times 10^{-8}, 4.0$ to $6.0, \times 10^{-7}$, and 2.5 to $2.8 \times$ $10^{-6} \mathrm{M}$, respectively. In our studies we found an identical rank order with $1 \mathrm{C}_{50}$ values of $9 \times 10^{-9}, 1.4 \times 10^{-7}$, and $6.2 \times 10^{-7} \mathrm{M}$, respectively. These $\mathrm{IC}_{50}$ values are also very close to those reported for 5-HT uptake in brain synaptosomes (see Green and Costain, 1981). In a previous study (Kimelberg and Pelton, 1983) we had found an $\mathrm{IC}_{50}$ value for inhibition of $\left[{ }^{3} \mathrm{H}\right]$ norepinephrine uptake by desmethylimipramine in primary astrocyte cultures of $2 \times 10^{-9} \mathrm{M}$. In comparison, an $\mathrm{IC}_{50}$ of $6.2 \times 10^{-7} \mathrm{M}$ for inhibition of $\left[{ }^{3} \mathrm{H}\right]-5-\mathrm{HT}$ uptake by desmethylimipramine was found in the present study, thus indicating considerable specificity of desmethylimipramine for the catecholamine system in the astrocyte cultures. In addition, we now find that the highly selective 5-HT uptake antagonist, fluoxetine (Wong et al., 1975), is very effective in inhibiting $\left[{ }^{3} \mathrm{H}\right]-5-\mathrm{HT}$ uptake in primary astrocyte cultures. The $\mathrm{IC}_{50}$ value of $2.3 \times 10^{-8} \mathrm{M}$ for fluoxetine found in the present study is close to the value of $6 \times 10^{-8} \mathrm{M}$ quoted for inhibition of 5-HT uptake in rat brain synaptosomes (Wong et al., 1975). The much higher $I C_{50}$ value of $4.9 \times 10^{-6} \mathrm{M}$ found for mianserin in the present study is also close to the value of $8 \times 10^{-6}$ $M$ found for rat brain synaptosomes (Green and Costain, 1981).

Other studies have also reported uptake of $5-\mathrm{HT}$ by various glia preparations with varying degrees of similarity and dissimilarity to the results reported in this paper for primary astrocyte cultures. Henn and Hamberger (1971) first reported a 6-fold concentration of serotonin at an external concentration of $10^{-7} \mathrm{M}$ by glial fractions isolated from rabbit brain by gradient centrifugation. Uptake of $\left[{ }^{3} \mathrm{H}\right]-5-\mathrm{HT}$ by the all-glial cell body filum terminale preparation from frog, which was $\mathrm{Na}^{+}$and temperature dependent and had a $K_{m}$ for $\left[{ }^{3} \mathrm{H}\right]-5-\mathrm{HT}$ of $0.7 \mu \mathrm{M}$, has been reported (Ritchie et al., 1981). Uptake of $\left[{ }^{3} \mathrm{H}\right]-5$ $\mathrm{HT}$ by the $\mathrm{C}_{6}$ glial tumor cell line in the presence of the MAO inhibitor nialamide has also been reported (Suddith et al., 1978). One component of this uptake was markedly $\mathrm{Na}^{+}$dependent. It had a somewhat high $K_{\mathrm{m}}$ of 1 to $2 \mu \mathrm{M}$ and was inhibited by chlorimipramine and desmethylimipramine at relatively high concentrations, with $\mathrm{IC}_{50}$ values of about $10^{-5} \mathrm{M}$. The effect of fluoxetine was not examined. Similar results for uptake of $\left[{ }^{3} \mathrm{H}\right]-5-\mathrm{HT}$ by $\mathrm{C}_{6}$ glial cells were recently reported by Whitaker et al. (1983). A relatively high $K_{m}$ of $2.2 \mu \mathrm{M}$ was also found, and the $\mathrm{IC}_{50}$ values for chlorimipramine and desmethylimipramine were 28 and $>1000 \mu \mathrm{M}$, respectively. In this study it was not stated whether an MAO inhibitor was added. In studies using primary cultures, Tardy et al. (1982) reported uptake of $\left[{ }^{3} \mathrm{H}\right]$ 5 -HT by primary astrocyte cultures from mouse brain with a $K_{m}$ of $0.17 \mu \mathrm{M}$ and a $V_{\max }$ of $0.6 \mathrm{pmol} / \mathrm{mg}$ of protein $/ \mathrm{min}$. Uptake was inhibited by chlorimipramine and fluoxetine, but again only at very high concentrations of $10^{-4} \mathrm{M}$. Also, it was not mentioned whether an MAO inhibitor was added in this study. Hansson (1983) has published autoradiographic studies of uptake of $10^{-6} \mathrm{M}\left[{ }^{3} \mathrm{H}\right]-5-\mathrm{HT}$ by rat primary astrocyte cultures in the presence of pargyline. The data were reported qualitatively, and "weak" accumulation of $\left[{ }^{3} \mathrm{H}\right]-5-\mathrm{HT}$ was described relative to "intense" accumulation of ${ }^{3} \mathrm{H}$-glutamate.
Our results with autoradiography confirm and extend the studies of Hansson (1983).

There have been a number of experiments on the uptake of $\left[{ }^{3} \mathrm{H}\right]$ $5-\mathrm{HT}$ in brain regions as studied by autoradiography which have not indicated a strong glial component. In studies at the light microscope level, uptake of $\left[{ }^{3} \mathrm{H}\right]-5-\mathrm{HT}$ was interpreted as uptake into nerve endings since uptake was found between nerve cell bodies and in regions known to hve a high concentration of serotonergic nerve endings (Fuxe et al., 1968). More direct evidence from electron microscopic autoradiography has localized around $80 \%$ of the grain clusters as being over nerve endings and axons, and only about $5 \%$ over glia and blood vessels (Aghajanian and Bloom, 1967). However, a recent study using electron microscopic autoradiography (Ruda and Gobel, 1980) did localize grains to astrocyte processes in a section from cat medulla after topical application of $\left[{ }^{3} \mathrm{H}\right]-5-\mathrm{HT}$ and pretreatment of the animal with an MAO inhibitor. Surgical lesions of the midbrain raphe nuclei or chemical lesion by injection of 5,6or 5,7-dihydroxytryptamine, which appear to selectively destroy serotonergic neurons (Björklund et al., 1973; Breese and Cooper 1975), also selectively inhibited high affinity uptake of 5-HT by brain (Kuhar et al., 1972; Björklund et al., 1973). The majority of these studies certainly suggest a more intense uptake and/or storage in nerve endings but cannot definitely rule out a contribution of high affinity glial uptake associated mainly with subsequent metabolic degradation by MAO. As mentioned above, one in vivo study in the cat did detect uptake into CNS astrocytes (Ruda and Gobel, 1980), suggesting that our findings in culture do represent an in vivo situation. It is also not clear whether the lesion studies are completely specific. Thus, destruction of serotonergic neurons may have indirect effects on astroglia surrounding such nerve endings. Also, we have recently observed that chronic treatment with 5,7-dihydroxytryptamine inhibits $\left[{ }^{3} \mathrm{H}\right]-5-\mathrm{HT}$ uptake in primary astrocyte cultures (D. M. Katz and $\mathrm{H}$. K. Kimelberg, unpublished observations).

In conclusion, our studies clearly show high affinity uptake of $\left[{ }^{3} \mathrm{H}\right]$ $-5-\mathrm{HT}$ by rat brain astrocytes in primary culture. In its kinetics, ion dependence, pharmacology of inhibition, and, also, its concentrative capacity it is indistinguishable from that found in various brain preparations, which is usually attributed to uptake by serotonergic nerve endings. If our results on normal astrocytes in culture can be extended to astrocytes in situ, then uptake by such cells is likely to be a significant route for the termination of action of 5-HT and a site of action for pharmacological compounds, such as the antidepressants. Such uptake into astroglia would presumably occur in addition to reuptake into nerve endings. The relative contributions of neurons and astroglia to uptake could be assessed if selective inhibitors of astroglial and neuronal uptake can be found. Screening for such compounds could conveniently be done in astroglial and neuronal culture systems.

\section{References}

Aghajanian, G. K., and F. E. Bloom (1967) Localization of tritiated serotonin in rat brain by electron-microscopic autoradiography. J. Pharmacol. Exp. Ther. 156: 23-30.

Björklund, A., A. Nobin, and M. Stevini (1973) Effects of 5,6-dihydroxytryptamine on nerve terminal serotonin and serotonin uptake in the rat brain. Brain Res. 53: 117-127

Bliss, C. E., and A. T. James (1966) Fitting the rectangular hyperbola. Biometrics 22: 573-602

Bogdanski, D. F., A. H. Tissari, and B. B. Brodie (1970) Mechanism of transport and storage of biogenic amines. Effects of sodium and potassium on kinetics of 5-hydroxytryptamine and norepinephrine transport by rabbit synaptosomes. Biochim. Biophys. Acta 219: 189-199.

Breese, G. R., and B. R. Cooper (1975) Behavioral and biochemical interactions of 5,7-dihydroxytryptamine with various drugs when administered intracisternally to adult and developing rats. Brain Res. 98: 517-527.

Fonnum, F., R. L. Karlsen, D. Malthe-Sorenssen, S. Sterri, and I. Walaas (1980) High affinity transport systems and their role in transmitter action. In The Cell Surface and Neuronal Function, C. W. Cotman, G. Poste, and G. L. Nicolson, eds., pp. 455-504, Elsevier-North Holland Publishing Co., Amsterdam. 
Frangakis, M. V., and H. K. Kimelberg (1984) Dissociation of neonatal rat brain by dispase for preparation of primary astrocyte cultures. Neurochem. Res. 9: 1685-1693.

Fuxe, K., T. Hökfelt, M. Ritzen, and U. Ungerstedt (1968) Studies on uptake of intraventricularly administered tritiated noradrenaline and 5-hydroxytryptamine with combined fluorescence, histochemical and autoradiographic techniques. Histochemie 16: 186-194.

Green, A. R., and D. W. Costain (1981) Pharmacology and Biochemistry of Psychiatric Disorders, pp. 71-88, John Wiley \& Sons, Inc., New York.

Hansson, E. (1983) Accumulation of putative amino acid neurotransmitters, monoamines and D-Ala ${ }^{2}$-Met-enkephalinamide in primary astroglial cultures from various brain areas, visualized by autoradiography. Brain Res. 289 . 189-196.

Henn, F. A., and A. Hamberger (1971) Glial cell function: Uptake of transmitter substances. Proc. Natl. Acad Sci. U. S. A 68: 2686-2690.

Hertz, L. (1982) Astrocytes. In Handbook of Neurochemistry, A. Lajtha, ed., Vol. 1, pp. 319-355, Plenum Press, New York.

Hoffman, D. W., and A. Vernadakis (1979) Biochemical characterization of $\left[{ }^{3} \mathrm{H}\right]$ norepinephrine uptake in dissected brain cell cultures from chick embryos. Neurochem. Res. 4: 731-746.

Iversen, L. L. (1974) Uptake mechanisms for neurotransmitter amines. Biochem. Pharmacol. 23: 1927-1935.

Kimelberg, H. K. (1983) Primary astrocyte cultures-A key to astrocyte function. Cell. Mol. Neurobiol. 3: 1-16.

Kimelberg, H. K., and D. M. Katz (1984) High affinity uptake of $\left[{ }^{3} \mathrm{H}\right]$ serotonin by primary astrocyte cultures from rat brain. Soc. Neurosci. Abstr. 10: 766.

Kimelberg, H. K., and E. W. Pelton (1983) High-affinity uptake of $\left[{ }^{3} \mathrm{H}\right]$ norepinephrine by primary astrocyte cultures and its inhibition by tricyclic antidepressants. J. Neurochem. 40: 1265-1270.

Kimelberg, H. K., C. L. Bowman, S. Biddlecome, and R. S. Bourke (1979) Cation transport and membrane potential properties of primary astroglial cultures from neonatal rat brains. Brain Res. 177: 533-550.

Kuhar, M. J., R. H. Roth, and G. K. Aghajanian (1972) Synaptosomes from forebrains of rats with midbrain raphe lesions: Selective reduction of serotonin uptake. J. Pharmacol. Exp. Ther. 181: 36-45.

Lindegjaerde, O., Jr. (1971) Uptake of serotonin in blood platelets in vitro. I. The effects of chloride. Acta Physiol. Scand. 81: 75-83.

Pelton, E. W., H. K. Kimelberg, S. V. Shipherd, and R. S. Bourke (1981) Dopamine and norepinephrine uptake and metabolism by astroglial cells in culture. Life Sci. 28: 1655-1663.

Pfister, C., and K. Goworek (1977) Fluoreszenzhisitochemische untersuchungen zur aufnahme von exogenem noradrenalin und dopamin durch in vitro kultivierte cerebrocortex-explantate der ratte. Z. Mikrosk. Anat. Forsch. 91: $521-535$.

Ritchie, T., S. Glusman, and B. Haber (1981) The filum terminale of the frog spinal cord, a nontransformed glial preparation. II. Uptake of serotonin. Neurochem. Res. 6: 441-452.

Ruda, M. A., and S. Gobel (1980) Ultrastructural characterization of axonal endings in the substantia gelatinosa which take up $\left[{ }^{3} \mathrm{H}\right]$ serotonin. Brain Res. 184: 57-83.

Shaskan, E. G., and S. H. Snyder (1970) Kinetics of serotonin accumulation into slices from rat brain: Relationship to catecholamine uptake. J. Pharmacol. Exp. Ther. 175: 404-418.

Snyder, S. H. (1970) Putative neurotransmitters in the brain: Selective neuronal uptake, subcellular localization, and interactions with centrally acting drugs. Biol. Psychiat. 2: 367-389.

Suddith, R. L., H. Hutchison, and B. Haber (1978) Uptake of biogenic amines by glial cells in culture. I. A neuronal-like transport system for serotonin. Life. Sci. 22: 2179-2188.

Tardy, M., M. F. D. Costa, C. Fages, J. Bardakdjian, and P. Gonnard (1982) I ptake and binding of serotonin by primary cultures of mouse astrocytes. Dev. Neurosci. 5: 19-26.

Whitaker, P. M., C. K. Vint, and R. Morin (1983) $\left[{ }^{3} \mathrm{H}\right]$ Imipramine labels sites on brain astroglial cells not related to serotonin uptake. J. Neurochem. 41 : 1319-1323.

Wong, D. T., F. P. Bymaster, J. S. Horng, and B. B. Molloy (1975) A new selective inhibitor for uptake of serotonin into synaptosomes of rat brain: 3-( $p$-trifluoromethylphenoxy)- $N$-methyl-3-phenylpropylamine. J. Pharmacol. Exp. Ther. 193: 804-811. 